\title{
Implications of Self Concept in Communication Behavior of Retarded Children
}

\author{
${ }^{1}$ NOVA YOHANA, ${ }^{2}$ FITRI HARDIANTI, ${ }^{3}$ RINA MARDIYANTI \\ 1,2,3 Jurusan Ilmu Komunikasi, Fakultas Ilmu Sosial IImu Politik, Universitas Riau \\ Kampus Bina Widya Jl. Hr. Soebrantas KM. 12.5 Simp. Baru Pekanbaru - 28293 \\ email: ${ }^{1}$ nova.yo7@gmail.com, ${ }^{2}$ fitri.hardianti94@gmail.com, ${ }^{3}$ rina.mardiyanti19@gmail.com
}

\begin{abstract}
In reality, the retarded children has a very sensitive position in the formation process of self-concept that works on their communication behavior in the social environment. This research article aims to express the implications of self-concept of behavior in both verbal communication and nonverbal communication of retarded children when they are interacting in a social environment. This research uses the qualitative method with symbolic interaction approach. The findings of the research indicate a positive self-concept of retarded children with the type of social comparison will have implications for their behavior of verbal communication become active and nonverbal communication become responsive. In reverse, negative self-concept of retarded children with the type of self-appraisal will have implications on verbal communication behavior become not optimally developed and nonverbal communication unresponsive.
\end{abstract}

Keywords: self-concept, retarded children, communication behavior, symbolic interaction

\section{Introduction}

Human as social beings will never stop to involve other humans to help them building a good self-concept in a sustainable manner. Individuals will have a good self-concept if he/ she is supported by the good understanding of himself/herself that he obtained from innerself and people around him/her. Whereas, the self-concept will be formed with poor quality if people see themselves as a weak figure, insignificant, shabby and all negative thoughts that coming from either their minds or others. Many factors have contributed to the formation of the self concepts, such as economic conditions, physical conditions, social conditions and etc (Laili, Nida, 2014:46).

One of the problems that often arises in the dynamics the development of selfconcept is contained in a child with Special disabilities as well as retarded children. The retarded children are a term that describes the child's condition whose intelligence is far below the average characterized by intelligence limitations and inadequacies in social interaction. The stigma that normal society gives to retarded children often equated with the following terms, feebleminded, mental retarded, stupid, witless, idiot, foolish, oligofrenia, full addiction, mental disability and intellectual disorders. The foreign language literature uses terms of mental retardation, mentally retarded, mental deficiency, mental defective, and others (Somantri, 2007: 103). The treatment to retarded children which tend to isolate them influence their psychological condition. Retarded children are also human who need to communicate and interact with others.

Retarded children, suffered a dysfunction in their brain, which caused their ability are limited almost all the functions that underlie in life processes. The retarded children are distinguished in various levels or degrees from mild to high level, namely (1) mild retarded children or capable learners; (2) medium retarded children or capable of training; (3) high retarded children and very heavy or

Received: August 5, 2016, Revision: November 15, 2016, Accepted: December 30, 2016

Print ISSN: 0215-8175; Online ISSN: 2303-2499. Copyright@2016. Published by Pusat Penerbitan Universitas (P2U) LPPM Unisba Accredited by DIKTI. SK Kemendikbud, No.040/P/2014, valid 18-02-2014 until 18-02-2019 
care needed (Amin, 1995: 11). The limited ability of the intelligence or intelligence below average caused retarded children have several difficulties, of which relates to the behavior of communication, both verbal and nonverbal and thus require special education services to help solve the problems and form a good self-concept to grow into a self-reliant and positive behavior.

Although retarded children have limitations, but basically, they also have dreams and desires just like any other normal child, the different lies on the development and level of intelligence. They also want to be recognized, appreciated and accepted by the neighborhood. This is because the existence itself of retarded children are also the same as a normal child. Self-existence in the neighborhood will greatly affect to person's self-concept. The basis of the individual's selfconcept implanted in the early moments of a child's life that eventually became the basis that affects his/her behavior in the future, including when the individual is responding to the stimulus he/she receives in the context of the communication.

Self concept for retarded children are awareness of retarded children regarding its involvement in the relationship or interaction with the neighborhood. The self-concept is formed not only from the viewpoint of themselves but also the viewpoints of others. The self-concept of retarded children can't be separated from the influence of parents' parenting and the environment, such as school environment involving teachers and social environment in the form of public view. The self-concept is formed through a process of learning ever since a human growth period from childhood to adulthood. with the childhood, as the most appropriate time to establishment the good personality.

George Herbert Mead denominates significant others (most important person) for the people around us with an important role in building our self-concept. When we were children, they are our parents, our brothers, and those who stayed at the same home with us. Richard Dewey and W.J. Humber named affective others, to others with whom we have emotional ties. From them, we build our selfconcept slowly. In addition, there is called the reference group is the group that emotionally bind us, and take effect on the establishment of ourselves. By looking at this, the person directing their behavior and adapt itself to the characteristics of the group (Yuniati,
Yuningsih, Nurrahmawati, 2015: 447)

The school is one of the places to make social connection social with surroundings. In the school of retarded children, they could do interaction with the teacher, friend or even someone else. For children with special needs (SDLB) 041 Bangkinang is one of the special needs education in the Bangkinang, Kampar regency of Riau Province which provides education for retarded children. All of the retarded students in SDLB 041 Bangkinang are human with potential that can be developed in order to achieve self-reliance, creativity and productivity. Schools or teachers also effect to the self-concept of retarded children. The education that provided in the schools aimed to develop the skills and abilities of children. If in ordinary schools, education is given with the purpose the students can be smart and get the achievement but in extraordinary school the education is given to build selfdevelopment, self-reliance and also providing skills to the children.

The social process that going through by retarded children will show how far the child is able to interact, adapt and organize the people around him. If the child is sociable, he/she can interact and adapt with social life and considered extroverted and organized so that he/she can be accepted easily by the surrounding community. However, if the child can not be interact, banged, and disorganized, he will get the problem to interact with other people and society will also close to the child. Positive or negative self concept in retarded children are determined because of the values instilled by parents and the influence of the environment, as well as how the child interpret the values provided through interactions made between him and the others.

This article aims to reveals the implications of self-concept in communication behavior both verbal and nonverbal at retarded children in SDLB 041 Bangkinang. This study uses qualitative method that aims to understand the phenomenon of what is experienced by the subject of the study such as behavior, perception, action motivation, etc., Holistically, by describe it into words and language, in a specific context in which the natural and by using various natural methods (Moleong, 2007: 6).

In this study, researchers choose symbolic interaction approach as research methods to understand the meaning of development retarded self-concept that has 
implications for the development of verbal and nonverbal communication behavior of retarded children. As stated by Blumer (in Basrowi, Sukidin, 2002: 142-143), the methodology adopted in the symbolic interaction approach has character typical in researching human behavior. The most fundamental propositions of symbolic interactionism are behavior and that human interaction can be distinguished because it is shown through symbols and their meanings. Self-concept on the theme of symbolic interaction emphasis on the development of self-concept through an individual inactive that is based on social interaction with other people.

The informants in this research are 6 (six) people of retarded children with various levels of retarded in Extraordinary Elementary School (SDLB) 041 Bangkinang. The key informants of this research are retarded children, their parents and their teachers, while the second informant is the principal, vice-principal, teachers, specialists retarded education and psychology experts. To get the data, the authors used three techniques of data collection, namely participant observation, indepth interviews, and documentation.

Table 1

Overview of Retarded Children as Informants

\begin{tabular}{|c|c|c|c|c|c|c|c|}
\hline No. & $\begin{array}{c}\text { Name } \\
\text { of } \\
\text { Student }\end{array}$ & Gender & $\begin{array}{c}\text { Age } \\
\text { (Years) }\end{array}$ & $\begin{array}{c}\text { Medical } \\
\text { History } \\
\text { and Devel- } \\
\text { opment }\end{array}$ & $\begin{array}{l}\text { Intel- } \\
\text { ligence } \\
\text { Level } \\
\text { (IQ) }\end{array}$ & $\begin{array}{l}\text { Educational } \\
\text { Background }\end{array}$ & $\begin{array}{l}\text { Parent's } \\
\text { Job }\end{array}$ \\
\hline 1 & $M Z$ & L & 12 & $\begin{array}{l}\text { During } \\
\text { toddler } \\
\text { always get } \\
\text { fever and } \\
\text { step }\end{array}$ & 74 & $\begin{array}{l}\text { Have } \\
\text { attended } \\
\text { school in } \\
\text { general } \\
\text { elementary } \\
\text { school }\end{array}$ & $\begin{array}{l}\text { Father is } \\
\text { traders of } \\
\text { cendol and } \\
\text { mother is } \\
\text { janitor }\end{array}$ \\
\hline 2 & $A L$ & $P$ & 13 & $\begin{array}{l}\text { Fall down } \\
\text { when TK } \\
\text { and get } \\
\text { head trauma }\end{array}$ & 64 & $\begin{array}{l}\text { Ever School } \\
\text { in SDN } \\
040 \text { Salo } \\
\text { Bangkinang }\end{array}$ & $\begin{array}{l}\text { Traders of } \\
\text { Pecel Lele }\end{array}$ \\
\hline 3 & GU & $P$ & 12 & $\begin{array}{l}\text { During tod- } \\
\text { dler always } \\
\text { get fever, } \\
\text { slow physi- } \\
\text { cal develop- } \\
\text { ment, and } \\
\text { neurological } \\
\text { disorders }\end{array}$ & 51 & $\begin{array}{l}\text { Went straight } \\
\text { to special } \\
\text { need-schools }\end{array}$ & $\begin{array}{l}\text { father: } \\
\text { handyman } \\
\text { of car seats } \\
\text { and mother: } \\
\text { housewife }\end{array}$ \\
\hline 4 & RA & L & 13 & $\begin{array}{l}\text { Rubella } \\
\text { virus, late in } \\
\text { speech }\end{array}$ & 58 & $\begin{array}{l}\text { Have } \\
\text { attended } \\
\text { Ever school } \\
\text { in SDN } 08 \\
\text { Bangkinang }\end{array}$ & $\begin{array}{l}\text { father: en- } \\
\text { trepreneur } \\
\text { and mother: } \\
\text { a housewife }\end{array}$ \\
\hline 5 & $\mathrm{MH}$ & L & 13 & $\begin{array}{l}\text { Neurological } \\
\text { disorders } \\
\text { that caused } \\
\text { by food } \\
\text { poisoning } \\
\text { and late in } \\
\text { handled (at } \\
4 \text { years) }\end{array}$ & 68 & $\begin{array}{l}\text { Have } \\
\text { attended } \\
\text { Ever school } \\
\text { in SDN } 011 \\
\text { Bangkinang }\end{array}$ & $\begin{array}{l}\text { father: } \\
\text { builder and } \\
\text { mother: } \\
\text { janitor }\end{array}$ \\
\hline 6 & MA & L & 14 & $\begin{array}{l}\text { Since } \\
\text { toddler } \\
\text { always } \\
\text { breathless } \\
\text { and late in } \\
\text { speech }\end{array}$ & 60 & $\begin{array}{l}\text { Ever school } \\
\text { in SDN } 037 \\
\text { Bangkinang }\end{array}$ & $\begin{array}{l}\text { father: } \\
\text { builder and } \\
\text { mother: } \\
\text { seller of rice } \\
\text { cake }\end{array}$ \\
\hline
\end{tabular}




\section{Profile of Retarded Children as Informant Research}

This section describe general thing about retarded children which become the subject of research (the informant). The data (profile) subjects research described in this section are taken from 041 Bangkinang SDLBN documents, interviews, and observations of researchers. In this paper the names of informants using initials to maintain the confidentiality of the informant's privacy as outlined in Table 1.

On Table 1 shows various of background of retarded children as an informant. Although they are in the same retarded community, but they have diverse characteristics. Judging from the diverse background of the parents, this is possible because elementary school for special needs children of SDLB 041 Bangkinang has characteristic open for all realm, under the guidance of Kampar education authorities and included one of SLB with the facilities and complete for schools level in district so these advantages is the reason why SDLB 041 Bangkinang is currently in great demand.

Parental background of retarded informant also quite diverse, especially in terms of employment, which is not a requirement for consideration or determination of the informants. It is most important for researchers that those who become research subjects are classified as retarded children who are capable to learn with classification based on the level of intelligence obtained from the student's section, apart from his/ her medical history and development which become important because it relates to retarded children development.

\section{Typology Self Concept of Retarded Children}

The self concept is an important aspect in a person because a person's self concept is a picture of a person about himself, which was formed through the experiences gained from interaction with the environment. The self concept is not an innate factor, but rather evolved from continuous and differentiable experience. Speaking about the behavior of existing communication in social interactions, especially interaction that occurs in retarded children in SDLB Negeri 041 Bangkinang, then the self concept is very important. The self-concept will be concerned with how the retarded people communicate, whether when retarded people are located in the neighborhood of people with the same retardation or in the general social environment that is different from their condition.

Retarded informants as social beings also have self concept despite its self-concept is only limited to ego of children who do not understand the negative or positive selfconcept. However, they still have an ego and self-concept evolved since childhood influenced by parenting parents, but their mental retardation which is rather late and makes them different from normal children. Samsunuwati Mar'at asserts that:

"The self concept of retarded-children is the same with other normal child which can be positive or negative. For instance some say can not, when he could. It is called the negative self-concept and the reverse... If the abused child closely with violence usually his self-concept is negative, from his expression he was inferior, he considered that he could not okay, if he considered all that bad then he will not be able to perform ... achievements will be built by self concept, confident, realistic rate, so do not expect to be mathematical has a low self-concept. There is a learning phase kill the concept of self. " (An interview with psychology person, Prof. Dr. Hj. Samsunuwati Mar'at, S.Psi, 29 September 2009).

Based on interviews and observations, it's known which informants have a positive or negative self-concept. Informants have a positive self-concept among MZ, GU, RA, $\mathrm{MH}$ and MA. They are said to have a positive self-concept because when they were in the neighborhood, they were convinced of its ability to overcome the problem, feel equal with others, realize everyone has feelings, has a desire and behavior approved of others, able to repair itself because it could reveal aspects he liked her personality and try to change it.

Only one person has a negative selfconcept as indicated by less willing to involve themselves in an environment that is perceived differently by his retarded condition ie $A \mathrm{~L}$, while interacting in a social environment he is more silent and has no confidence or his behavior relates to his deficiencies that he perceive subjectively and his self-consciousness becomes unrealistic. Nevertheless, AL can still interact flawlessly even his cultivated interpersonal interaction is still passive. In addition, informers who have negative self-concepts have characteristics that see themselves as inadequate, perceive peers and adults as less acceptable, show the 
less effective approach in solving the problem, show the freedom of emotional expression that is less adequate and more to express feelings of negative self.

The basis of the concept of individual self-implanted in the early moments of a child's life and becomes the basis that influences their behavior in the future. As expressed by Blumer (Poloma, 2007: 258), there are three underlying premise of symbolic interactionism thought namely: people act on something based on the meanings that exist in that thing that is considered to give effect to him, that meaning comes from a person's social interaction with others, and the meaning is enhanced when the process of social interaction takes place. Elaboration of the premise, namely; (1) human beings act upon the meaning given by individual to the social environment; (2) meaning directly related to social interaction done by individuals with their social environment; (3) meaning is created, maintained, altered through a process of interpretation by the individual in dealing with the social environment. Because individuals continue to change the society in which individuals communicate through interaction patterns also change what they do. So, this is interaction which is considered an important variable determining human behavior. Basic interaction is not off to do with the significant other parents.

The parental background will determine how to provide parenting to the retarded informant that eventually formed the different self-concept on each retarded informant. From the six retarded informants, they generally come from families with low socioeconomic status or below the average with job as merchants and laborers, and the background of elementary through high school education. It affects the way their parents delivered parenting to the retarded informant. Limited time of interaction and parental knowledge is rather impossible to apply by the informants parents, since they only consider about the terms of the basic necessities. Other significant limitations is in providing stimulation that make retarded informant failed to develop optimally. Zainal Alimin, expert of education children with special need, asserts:

"Retarded child's self concept is the same with another normal child which can be positive or negative. However, parents can affect the child's self-concept and behavior. Whether he will behave adaptively or otherwise. It depends on the parents, if the parents have the acceptable, objective, realistic atitudes, certainly the child shows a realistic attitude as well. Take it as it comes. For example: parents will bring their children to the invitation, ask to go to the mall when there is guess the child is introduced, this kind of growing is better and that if the parents feel shame, pride, children is hiden or never be expose, then the growth is inhibited. I have seen many if the acceptance is positive, the child will treat the child positively and the reverse, ... but there is also the attitude of parents which are very protective. That and also this are forbidden, it should not be, it will make the development of the self concept is worse (Interview with Zainal Alimin, child education expert of retarded children, Universitas Pendidikan Bandung, 10 November 2009).

The development of retarded people's self-concept can not be separated from how parents treat the mental retardation. If a child obtains a positive treatment, then he will develop a positive self-concept as well. The opposite is true when parents and those closest to the retarded children are unpleasant or even abusive then attached to the retarded child is something uncomfortable so the experience will continue to brought up at any stage of development. Children with intellectual challenges will be difficult to assess himself even when he/she interact with others.

George Herbert Mead (in Mulyana, 2006: 73) argues that the self or self-concept is a process that comes from the social interaction of individuals with others, or in the elucidation of the others, oneself (self) is also an "object social "that we share with others in an interaction. The self-concept is an arrangement of individual awareness regarding special engagement in the set of social relationships that are ongoing or in a community that is organized. Mead sees itself evolving from a similar state that embodies the spiritual, namely the emergence of significant symbols of social actions. Self as a social object means that the individual was acquiring meaning interpreted by others around him. Although the resignation was developed properly, he would change according to the changes of experienced by the group (Ahmadi, 2011: 167). A positive self concept will usually be shown by retarded people with an attitude that will not hesitate to be able to open up and receive input from the outside, the courage of expression, tend to have high motivation to achieve, able to actualize his potential, and is able to harmonize with its surroundings. Instead, the retarded people which have a negative self-concept is retarded as individuals who are not able to evaluate the meaning contained in the situation receives 
(cognitive assessment), and such kind of the situation will cause a pressure and threats to themselves, so that they can not resolve the problem appropriately. However, the development of self-concept not off to do with the treatment of the parent. If retarded people believe that people considered to be important loving them, then they will think positively about themselves, and vice versa if their important people do not love them, then they will think negatively of themselves. The self-concept is formed through a long process of a series of experiences that are perceived and interpreted by an individual (Sari, Wirman, 2015: 142)

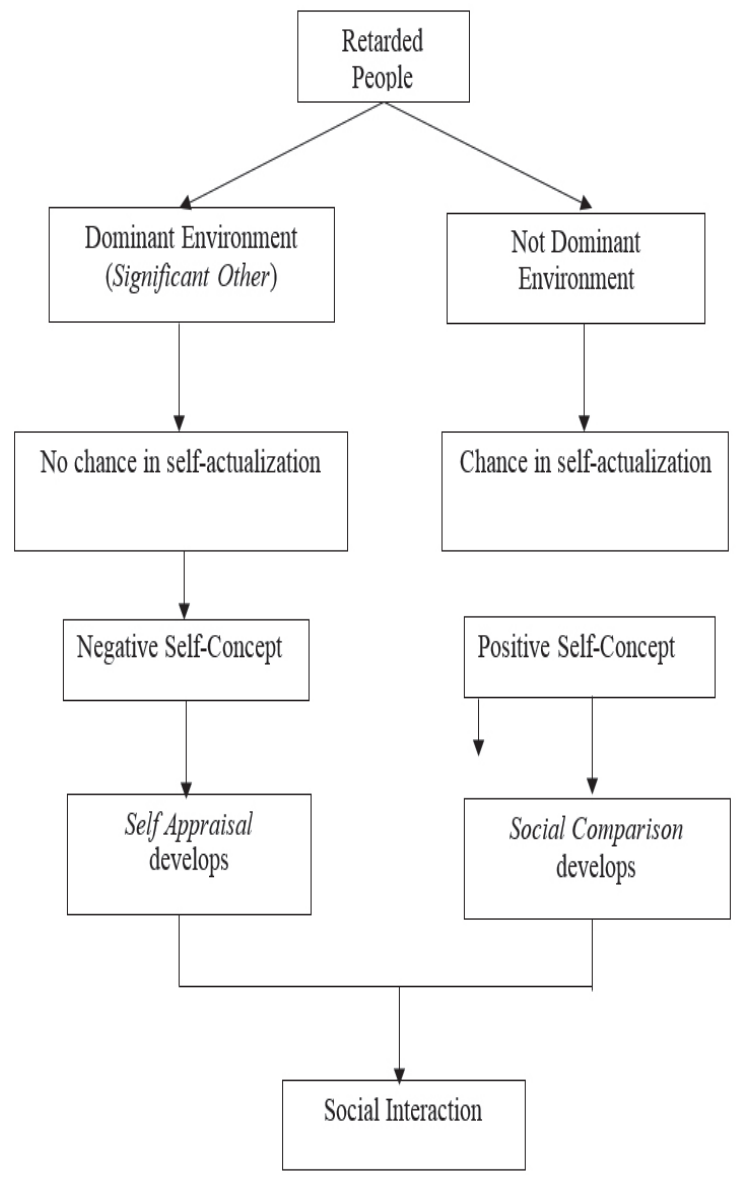

Figure 1

Self Concept Model of Retarded Children

Source: constructed based on research result

The picture of the retarded child's selfconcept formed of how the individual perceives himself and through the experience, especially the experience of the people closest to and who gives meaning to the intellectual challenges. From the self-concept, can be defined two typological concepts of self-informant children with intellectual challenges: first, a negative self-concept type of self-appraisal is a selfconcept formed of how that individual looked at himself, in which the retarded children can not express themselves because what grows are dominant patterns of behavior, those are the parents. Second, positive self-concept type social comparison is a self-concept formed from what he feels about himself with what others valued about themselves. Type the self-concept owned by retarded informant that constructed by researchers based on the research result looks like on Figure 1.

\section{Implications of Self Concept toward Verbal Communication Behavior Retarded Children}

Verbal communication behavior of retarded children are a form of interpersonal communication behavior that happened between retarded children and their social environment and can not be separate from symbolic interaction's approach. The dominant social environment's handling is other significant factor that mainly parents will establish a self-concept of retarded who bear a certain attitude of self. Each tunagrahita thus forming a distinctive community that can be seen from their verbal communication.

Based on the observations that conducted to the retarded children who attend school in SDLB, it is obvious that they also wanted to communicate and felt a sense like the desire to be accepted in environments outside their community which normal child have. They always send messages consciously and unconsciously to be accepted by the neighborhood, although unconsciously selfconcept has been established and influence prior for these conditions.

One of the verbal communication behaviors the retarded children have is a limitation in using the language. Short of behavior (deficient) is a speech disorder which caused the message sometimes conveyed through nonverbal language (Rachmat, 2005: 184). Results of the study also found that the vocabulary of retarded children are less varied, besides words that taught and used in every day in a single conversation which tend to be simple. When you are talking, then he would immediately call himself as the subject or the name of another person. Eisenson and Ogilvie 1963 (in Effendy, 2006: 99) research to find the relationship between the level of intelligence with language and speech abilities. The results showed that the level of intelligence with a maturity of language and speech has a positive relationship.

Besides the fact, the study also get 
results that they have a particular form of verbal communication that is associated with pronunciation problems, the quality of sound and rhythm. The pronunciation is not clear, heavy sound quality and talk fast rhythm can make disturbances in verbal communication. Verbal communication disorders that occur in the above tunagrahita usually associated with physiological disorders that are disturbances due to the inconvenience of going to physical problems such as difficulty articulating.

Besides the issue of pronunciations, the quality of sound and rhythm, retarded students after repeat the syllables, omission or eliminate one letter, a slip of the sound's word, flip over in saying the word, and stuttering. Somantri (2007: 114) revealed the cognitive development of retarded children go through barriers, therefore the language development also be hampered. Retarded children generally can not use complex sentences, in everyday conversation using a single sentence.

However, communication skill of tunagrahita (retarted) is not only influenced by the intellectual level but also influenced on how often communication is done with people around him. The role of the close person especially parents is important to establish how verbal communication of tunagrahita. If we would be given the opportunity for retarded children to express themselves, the more chance of developing a vocabulary that would further develop the retarded children active verbal communication. Conversely, when parents and closed people do not provide many opportunities for retarded children then communication will not develop optimally. Samsunuwati Mar'at, as resource persons of psychology confirms:

If the IQ is lower means, it means that children totally do not understand anything, even and hard to understand the words, but IQ and the socialization of the child are completed each other. If the brain always sharpened it will be keen, if the skill of speech always be horned, they will getting accustomed to speak the same way as, teach children like teaching a toddler to talk, and requires patient, it will be difficult to show the rapid as progress directly as progress in a normal child. (Interview with resource persons of psychology, Prof. Dr. $\mathrm{Hj}$. Samsunuwati Mar'at, S.Psi, 29 September 2009).

Verbal communication is not widely used by informants in formal situations, especially during the learning process. They are freer to express themselves through verbal communication during informal situations because they feel in that situation of the social environment took it well and make retarded children become comfortable. One important thing that occurs at retarded children in SDLB 041, they generally use local languages (Malay Kampar), if using the Indonesian language they mix with regional languages or become bilingual, is influenced by the environment in which the majority of retarded informants use local languages in their daily lives. So retarded children more identify and understand the local language compared to Indonesian.

The self-concept that developing positive self will determine the development of verbal communication becomes active, otherwise retarded children with negative self-concept will make verbal communication do not develop optimally, as there is only one form of verbal communication are growing, especially in writing. But that is typically found in retarded children in SDLB 041 Bangkinang who has limited verbal skills.

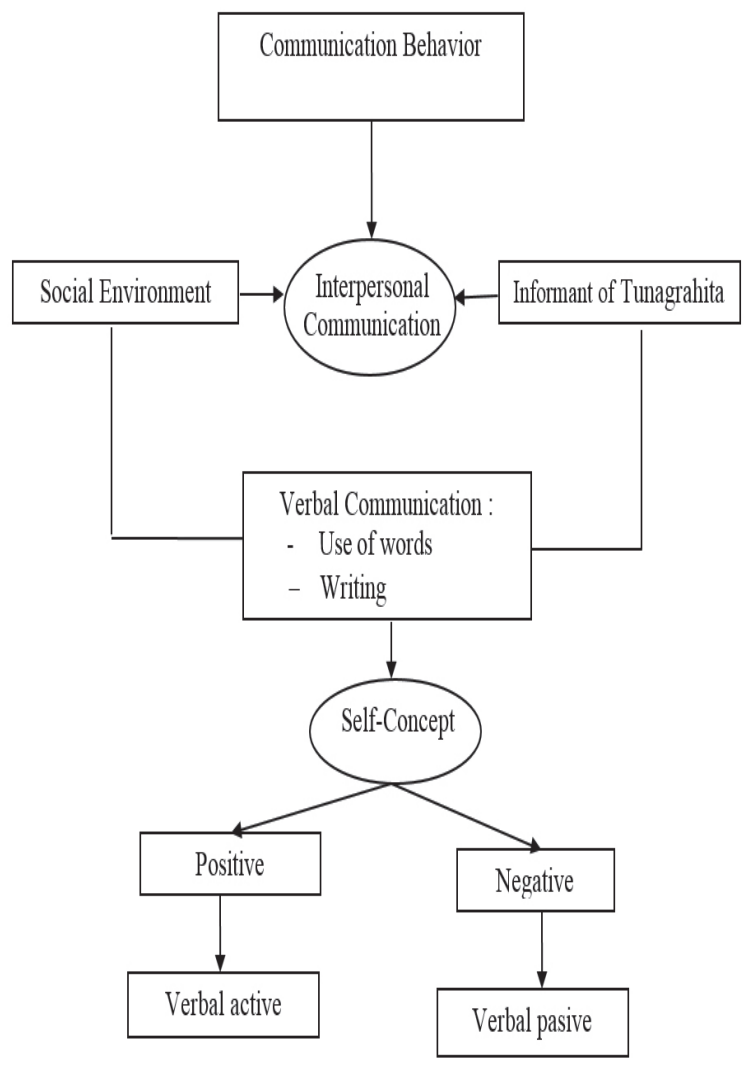

Figure 2

Implications model of self- concept in verbal communication behaviors of Retarded children

Source: constructed based on research results

The self-concept that formed the retarded informants are various depend on 
education background and employment of significant other. Background of employment and education related to quality and quantity provision of parenting as a basis for the establishment and development of selfconcept. Lack of parental knowledge of child development will make the children do not grow and develop optimally because the parent is a person who provides large stimulation so that retarded children as informant who are able to actualize themselves. When retarded children can not actualize themselves will have an impact on the limited ways of communication and socializing with friends or with others, as a consequence of formation of self-concept which does not develop optimally. The results of the study related to implications of selfconcept in verbal communication behavior of retarded children can be formulated into a model as shown in Figure 2.

\section{Implications of Self-Concept toward Nonverbal Communication Behavior Retarded children}

In real life of retarded children, nonverbal communication often widely used than verbal communication because nonverbal communication much more honest and spontaneously revealed things would be disclosed. However, despite the non-verbal communication is more widely used and honest, but more difficult to interpreted. Nonverbal communication usually complements the verbal message and vice versa. Besides verbal and nonverbal communication also reinforce and support each other so that all component of verbal and nonverbal systems will work together to communicate a specific meaning.

Curiosity expressed by nonverbal language of retarded children are influenced by various factors as one of the very important roles are the parents. The similarity in the treatment of significant other especially parents on their self-concept eventually formed a similarity of behavior based on nonverbal communication which they often do, when they're doing the interaction. Appearance or fashion, the level of eye contact, face expressions, body movements and etc has given instructions for the researcher to make that assessment.

Another important thing gained from nonverbal communication is that it tends to be communicative, since nonverbal behavior in interaction will always communicate something. As well as it happened to informants, as a community that is different from normal child, informant of retarded children wants to communicate everything including their curiosity toward others in his own way.

Nonverbal communication of retarded children similar to those used with other kids it is just that in tungrahita children will be more expressive, for example when he/she does not like the teacher, the child will show it with a frown. One important thing is that if there are things that touch affection or a feeling that they will easily catch the hint and more often respond not by reason (Interview with Samsunuwati Mar'at, resource persons psychologist from Universitas Padjadjaran, 29 September, 2009).

All forms of nonverbal communication no matter how small is very important because all of it has meaning. Similarity form of nonverbal communication that doing by retarded children may indicate that they are like each other and feel comfortable with the community.

Each individual included retarded children able to perform non-verbal communication, but how often and use a lot of non-verbal communication is very different, for example; someone prominent in kinesik components, appearance and haptic, while others stand in proksemik components and appearance, some even includes just one non-verbal communication. (Interview with Zainal Alimin, child education expert of retarded children, Universitas Pendidikan Bandung, 10 November 2009).

There are limitations on retarded children which will not affect them when them carry out interpersonal communication. Because of the common identity that has already formed, it is easier for them to express themselves and interact more intensely with its environment. An identity they have can help them recognize and accept themselves as the others accept them, so he also can act as generally expected by the environment. Just as when they do the communication, after the message sent through the communications media, the message can be received, interpreted, read and construed directly or indirectly through the thought process, as a response to the messages received by the communicant will bring actions, in other words the process of symbolic interaction will be held with demonstration through verbal and nonverbal language or even both are used simultaneously. The self-concept will determine how much ability of retarded children utilize nonverbal communication, to resolve 


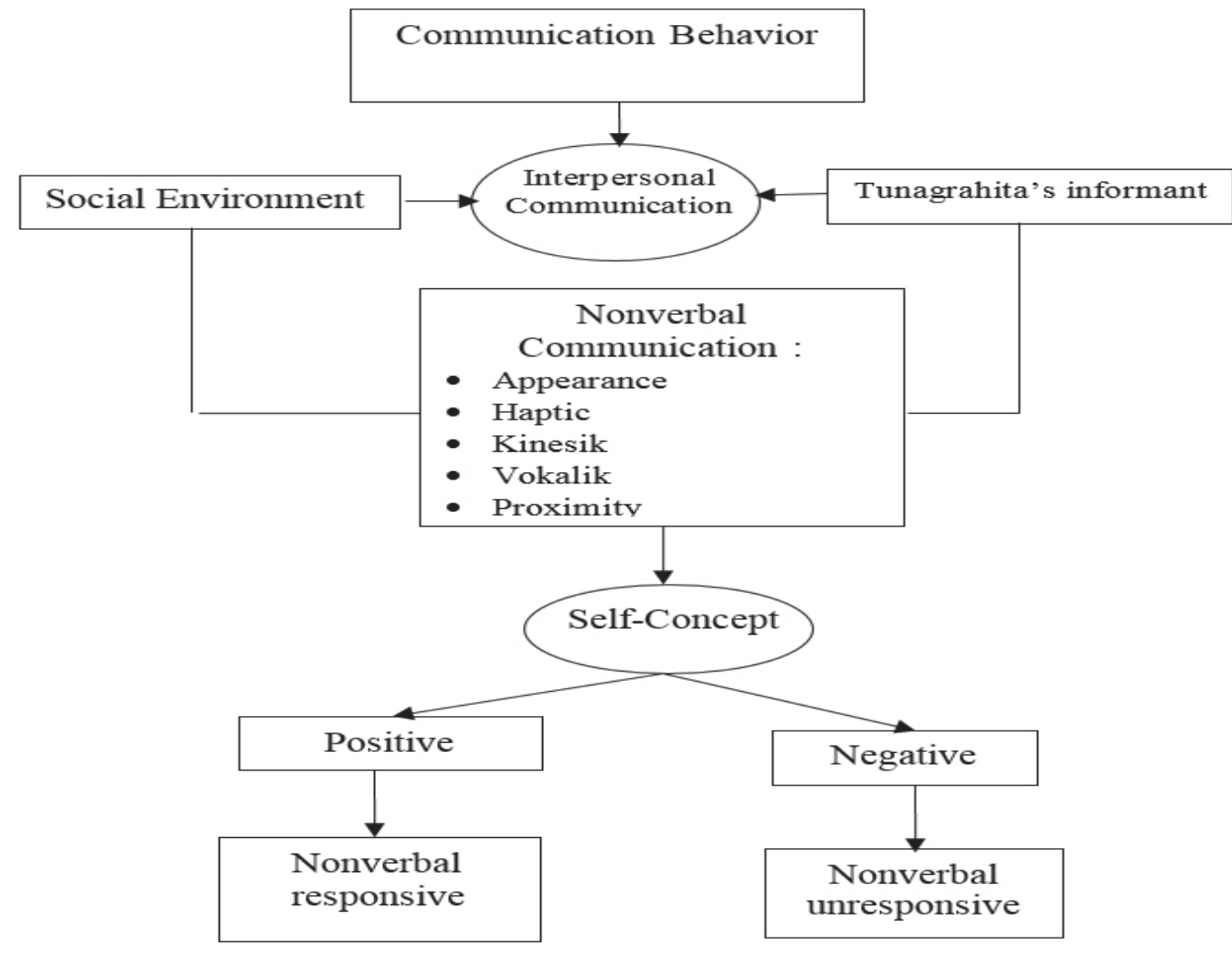

Source: constructed based on research results

Figure 3

Implications model of Self-Concept in Nonverbal Communication Behavior of Retarded children

deficiency of their verbal communication. Sketchily implications model of self-concept in non-verbal communication behavior of retarded children which constructed by the author based on the results shown in Figure 3.

\section{Conclusions}

Self-concept of retarded children is not something isolated and also hidden but, depending on the reactions and responses of others. Family conditions, daily activities, parenting, and learning system in the school also affects the self-concept of retarded children. Judging from the ability to interact in the SDLB 041 Bangkinang, retarded children have a positive self-concept type of social comparison which derived from what is perceived concerning himself with what is valued by others against him, which has implications for the development of verbal communication to become active, and the ability of retarded children utilize nonverbal communication is more varied to handle verbal communication.

In contrast, retarded children with negative self-concept type of self-appraisal in which self-concept are not fully developed informant lack of expressing themselves due to during the growing process is the behavioral patterns of the most dominant, namely parents, implicated in verbal communication which do not develop optimally, and nonverbal communication is limited to one or two variations used to express and reinforce the verbal message.

It is advisable for parents and teachers to have a good understanding of what care and education can be provided for retarded children to form a good self-concept for them that someday in the future they can be independent and even contribute to the environment around them. The level of acceptance and support given by the community will greatly affect the self-concept of retarded children for interaction and communication well. 


\section{References}

Ahmadi, Dadi. (2011). Pemaknaan Hakikat Diri Akuntan Publik . Jurnal MIMBAR, Vol. XXVII, No. 2 (Desember 2011): 165-172. Bandung: P2U LPPM Unisba

Amin, M. (1995). Ortopedagogik Anak Tunagrahita, Bandung: Dirjen Pendidikan Tinggi Depdiknas

Basrowi dan Sukidin, (2002), Metode Penelitian Kualitatif Perspektif Mikro. Surabaya: Insan Cendekia.

Effendy, Mohammad. (2006). Pengantar Psikopedagogik Anak Berkelainan. Jakarta: Bumi Aksara

Laili, Fatma dan Nida Khoirun. (2014) . Membangun Konsep Diri bagi Anak Berkebutuhan Khusus. Jurnal Thufula. Vol 2. No. 1. Januari- Juni 2014

Moleong, Lexy J. (2007). Metodologi Penelitian Kualitatif. Bandung Remaja Rosdakarya.
Mulyana, Deddy. (2006). Metodologi Penelitian Kualitatif. Bandung : Remaja Rosdakarya.

Poloma, Margaret M. (2007). Sosiologi Kontemporer. Jakarta: PT. Raja Grafindo Persada

Rakhmat, Jalaluddin. (2005). Psikologi Komunikasi. Bandung: Remaja Rosdakarya

Sari, Gustina Genny dan Wirman, Welly. (2015). Konsep Diri Perempuan Pelaku Pembunuhan. Jurnal MIMBAR. Vol 31. No.1.(Juni 2015).1-262. Bandung: P2U LPPM Unisba

Somantri, Sutjihati. (2007). Psikologi Anak Luar Biasa. Bandung: Refika Aditama.

Yuniati, Yenni, Yuningsih Ani, dan Nurrahmawati. (2015). Konsep Diri Remaja dalam Komunikasi Sosial melalui "Smartphone". Jurnal MIMBAR. Vol 31. No 2. (Desember 2015) 263-532. Bandung: P2U LPPM Unisba 